\title{
An Assessment of Permanent and Nonpermanent Plots in Riparian Vegetation Monitoring
}

\author{
Author(s): Caroline M. Laine, Karin M. Kettenring and Brett B. Roper \\ Source: Western North American Naturalist, 73(3):337-346. 2013. \\ Published By: Monte L. Bean Life Science Museum, Brigham Young University \\ DOI: http://dx.doi.org/10.3398/064.073.0307 \\ URL: http://www.bioone.org/doi/full/10.3398/064.073.0307
}

BioOne (www.bioone.org) is a nonprofit, online aggregation of core research in the biological, ecological, and environmental sciences. BioOne provides a sustainable online platform for over 170 journals and books published by nonprofit societies, associations, museums, institutions, and presses.

Your use of this PDF, the BioOne Web site, and all posted and associated content indicates your acceptance of BioOne's Terms of Use, available at www.bioone.org/page/ terms of use.

Usage of BioOne content is strictly limited to personal, educational, and non-commercial use. Commercial inquiries or rights and permissions requests should be directed to the individual publisher as copyright holder. 


\title{
AN ASSESSMENT OF PERMANENT AND NONPERMANENT PLOTS IN RIPARIAN VEGETATION MONITORING
}

\author{
Caroline M. Laine ${ }^{1,2}$, Karin M. Kettenring ${ }^{1}$, and Brett B. Roper ${ }^{1,3}$
}

\begin{abstract}
Aвstract.-The aim of this research was to determine whether permanent and nonpermanent plots for describing riparian plant communities would yield the same results. This research was conducted at 4 streams in central eastern Idaho. Permanent and nonpermanent greenline plots (first perennial vegetation adjacent to stream) were sampled repeatedly from June to October 2010, and we assessed differences between plot types by comparing species richness, wetland indicator rating, and percent cover of live vegetation, forbs, graminoids, litter/moss, and bare ground. We found few statistically significant differences between permanent and nonpermanent greenline plots. Because both types of plots yielded similar results, we suggest that nonpermanent plots are a better choice for riparian monitoring because they are defined by their spatial relationship to the stream, rendering a permanent marker unnecessary, and they are also less labor intensive.
\end{abstract}

RESUMEN.-El objetivo de esta investigación fue determinar si se obtienen los mismos resultados al describir las comunidades de plantas ribereñas en los terrenos permanentes y en no permanentes. Esta investigación se realizó en cuatro arroyos ubicados en la zona central este de Idaho. Se tomaron muestras repetidas de los terrenos verdes (primeras plantas perennes adyacentes al arroyo) permanentes y no permanentes entre junio y octubre del 2010, y analizamos las diferencias entre los tipos de terreno comparando la riqueza de especies, la clasificación del indicador de humedales, la cantidad de vegetación viva, las pasturas, las gramíneas, los desechos, el musgo y el suelo descubierto. Encontramos pocas diferencias significativas desde el punto de vista estadístico, entre los terrenos verdes permanentes y no permanentes. Como los dos tipos de terreno mostraron resultados similares, consideramos que los terrenos no permanentes son más indicados para el monitoreo ribereño porque se definen por su relación espacial con el arroyo, lo cual hace que no sea necesario colocar un indicador permanente, y, además, requieren menos trabajo.

Vegetation studies often use permanent plots because true changes in the plant community that are due to temporal variation, succession, or the effect of management can be detected while controlling for small spatial differences in an area (Pickett et al. 1987, Bakker et al. 1996, Scherrer and Pickering 2005). Although commonly employed in many types of terrestrial vegetation studies, this methodology has rarely been applied to riparian areas. Most research involving permanent riparian plots has focused on woody vegetation in forested areas (Sakio 1997, Bunyavejchewin 1999, Liang and Seagle 2002, Acker 2003, Van Pelt et al. 2006), and only a few studies have focused on herbaceous vegetation (Tabacchi 1995, Beever et al. 2005, Gerber et al. 2008). None of these studies placed permanent plots at the important location of the greenline, the area of ecological interest in many riparian monitoring protocols.

Winward (2000) developed the concept of greenline, defining greenline as "the first perennial vegetation that forms a lineal grouping ... on or near the water's edge." This vegetation plays an especially important role by acting as a buffer zone between the stream and terrestrial vegetation and by providing bank stability (Belsky et al. 1999, Winward 2000). In addition, greenline vegetation may have both better water availability than terrestrial vegetation farther from the river channel and the ability to rebound more quickly from disturbance, which makes greenline useful in determining if management activities, such as livestock grazing, are having a negative effect (Winward 2000). The greenline concept focuses on perennial vegetation because it is less susceptible to change between years and presumably has less variation between sampling periods than annual vegetation. Two protocols widely used for riparian monitoring by the United States Forest Service (USFS) and Bureau of Land Management (BLM) - the Pacific Fish/Inland Fish Biological Opinion (PIBO) protocol and the Multiple Indicator

\footnotetext{
1Department of Watershed Sciences, Utah State University, Logan, UT 84322.

2Present address: $4180 \mathrm{~W} 2600 \mathrm{~N}$, Benson, UT 84335. E-mail: lainecaroline@hotmail.com

${ }^{3}$ USDA Forest Service, Forest Sciences Laboratory, Logan, UT 84322.
} 


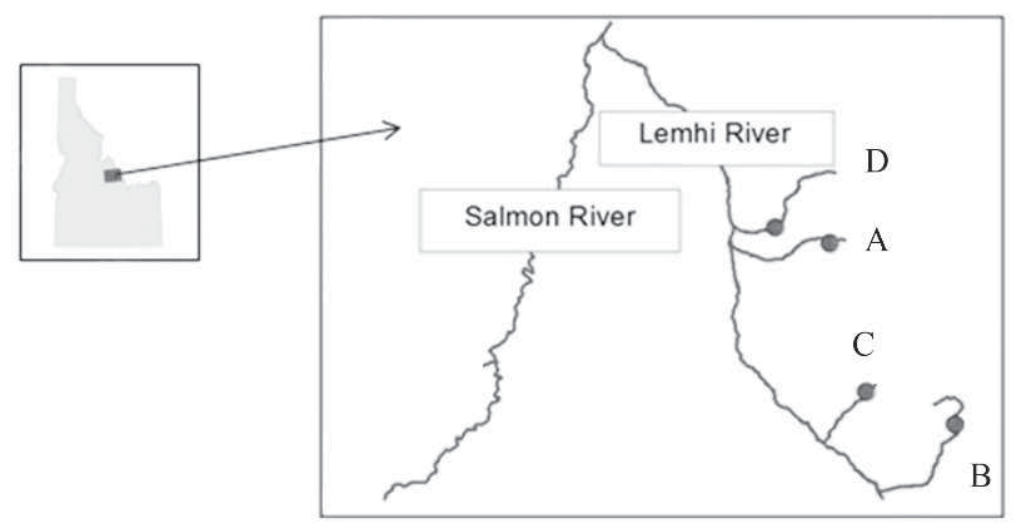

Fig. 1. Streams included in this study: A, Agency; B, Canyon; C, Little Eightmile; and D, Pattee.

TABLE 1 . Average rainfall and 24-h daily temperature in Leadore, Lemhi County, Idaho, USA, from June to October 1961-1990. (World Climate 2011).

\begin{tabular}{lcc}
\hline Month & Rainfall $(\mathrm{mm})$ & $\begin{array}{c}\text { 24-h average } \\
\text { temperature }\left({ }^{\circ} \mathrm{C}\right)\end{array}$ \\
\hline Jun & 22.8 & 15.4 \\
Jul & 19.7 & 19.2 \\
Aug & 15.7 & 18.2 \\
Sep & 17.7 & 13.2 \\
Oct & 18.6 & 7.3 \\
\hline
\end{tabular}

Monitoring (MIM) protocol-have expanded the definition of greenline to be the first plot with $25 \%$ perennial vegetation cover adjacent to the stream. This definition is more precise and makes it easier for field researchers to locate the greenline during riparian monitoring.

Greenline location may change seasonally with changes in river flow, grazing, or stream scouring. Also, even though streamside perennial vegetation persists for many years, there are periods in its life cycle where the vegetation may not be extensive enough or may have been grazed too heavily to qualify as greenline. These variations in greenline location make the use of permanent plots problematic and potentially misleading. On the other hand, personnel from the USFS saw potential problems with the repeatability of traditional (nonpermanent plot) greenline placement techniques and were interested in testing whether permanent greenline plots would have significantly different results than nonpermanent plots.

For this assessment, we compared commonly used response metrics (species richness, wetland indicator rating, and percent cover of live vegetation, forbs, graminoids, litter/moss, and bare ground) between permanent and nonpermanent plots.

\section{Study AREA}

This study was conducted in riparian areas of 4 streams in the Beaverhead Mountain Range of the Salmon National Forest and surrounding BLM lands in central eastern Idaho (Fig. 1). The elevation of the study sites ranged from $1560 \mathrm{~m}$ to $2300 \mathrm{~m}$, and the streams were 3-6 m wide at bankfull elevation. The semiarid climate is characterized by cold winters and warm summers, with most precipitation occurring as spring and summer rain and winter snow. The mean monthly rainfall during the study season of June to October is $19 \mathrm{~mm}$ per month, and the 24-h average temperature during the study season is 14.7 ${ }^{\circ} \mathrm{C}$ (Leadore, ID, weather station; World Climate 2011; Table 1).

\section{METHODS}

\section{Sampling Design}

In 2010 , we chose 4 streams that were used in a previous study (Laine 2011) and were accessible by road and trail. We focused our research at the greenline in stream meadows dominated by big sagebrush (Artemisia tridentata) and willow (Salix spp.). We used the PIBO protocol definition of greenline: the first plot with $>25 \%$ perennial vegetation adjacent to the stream, between the upper and lower limit (Leary and Ebertowski 2010). The upper limit was the first flat depositional feature at 


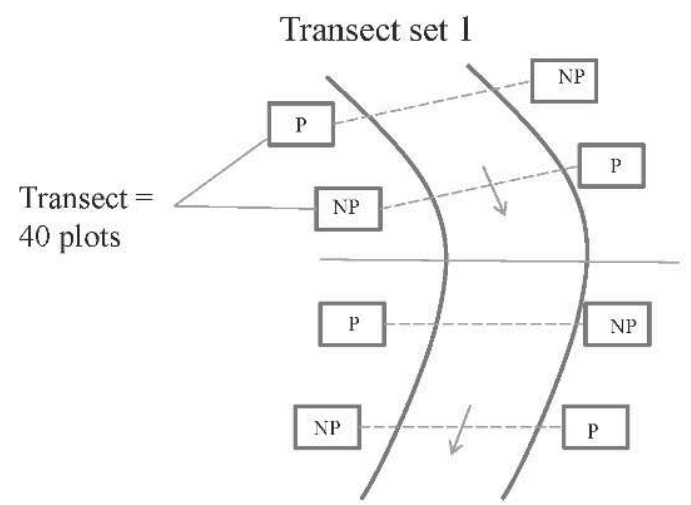

Transect set 2

Fig. 2. Sampling design: 4 transects per stream (in 2 sets) were sampled at each stream. Each transect had 20 permanent $(\mathrm{P})$ and 20 nonpermanent plots $(\mathrm{NP})$.

or above bankfull elevation, and the lower limit was where the streambed met the stream bank (Leary and Ebertowski 2010). Bankfull elevation was defined by Harrelson et al. (1994).

We measured 2 sets of 2 parallel transects per stream (Fig. 2). Transect sets were located within 100-1000 $\mathrm{m}$ of each other in the closest location that fit within the designated community type. We established 40 permanent greenline plots per transect in June 2009 for a previous study (Laine 2011). Each permanent plot was marked by driving a $15-\mathrm{cm}$ piece of rebar into each of 2 diagonal corners of a $20 \times$ 50 -cm plot, oriented with the $50-\mathrm{cm}$ side, parallel to the stream. Plot relocation in 2010 was aided with use of a metal detector. In 2010, we established 20 permanent and 20 nonpermanent plots on each transect, alternating type every $3 \mathrm{~m}$. The 20 permanent plots in 2010 were in the same location as in 2009 , whereas we established the nonpermanent plots along the same axis as the permanent plot from 2009 (perpendicular to the stream) and relocated them at each new sampling period based on the new location of greenline at the time of sampling. In order to assess the migration of greenline within the season, we measured the distance (in $\mathrm{cm}$ ) from the center of the permanent plot to the center of the nonpermanent plot. In each plot, at 2- to 3-week intervals for 20 weeks from 10 June to 20 October, we collected percent cover data ( $>5 \%$ cover in the plot) for all vegetative species (both herbaceous and woody species) and the following categories: bare ground, litter/moss, rock, and log. From this information, we obtained species richness, wetland indicator rating, and cover of live vegetation, forbs, graminoids, litter/moss, and bare ground. All metrics were derived from absolute percent ground cover, or the proportion of space that a given plant species or other vegetative category took up in a plot, by using cover class categories for each species or vegetative category. Species richness was the number of species within the plot that had $>5 \%$ cover. Live vegetation cover was defined as any living or dead plant material still attached to its living maternal plant. Litter/moss included any moss and senesced plant material no longer attached to a plant. Wetland indicator rating (WIR) for each species with $>5 \%$ cover was determined from Reed (1988), which rating is based on the likelihood, according to the USDA Plants Database, that the species will be found in a wetland area (USDA-NRCS 2011). The WIR value for a plot was the sum of the relative percent cover of each species multiplied by its wetland indicator rating. Derived from cover estimates, this metric is commonly used for assessing riparian health and change.

\section{Data Analysis}

Because of innate differences in the streams' past and present grazing histories, we analyzed each of the 4 study streams individually. We analyzed vegetation metrics using a oneway ANOVA in a randomized block design with repeated measures in time using a firstorder autoregressive structure to account for temporal autocorrelation. The fixed effects were plot type (permanent or nonpermanent) and week (8-9 levels). Transect was incorporated as a random block effect. Degrees of freedom were calculated using the Satterthwaite (1946) approximation. A square-root transformation was used on species richness, percent forb, and percent graminoid to better meet the model assumptions of normality and homogeneity of variance. We used an alpha of 0.05 as our critical significance level. Data analyses were obtained using the GLIMMIX procedure in SAS/STAT software version 9.2 in the SAS system for Windows (SAS Institute, Inc. 2008). We calculated means and standard errors for all metrics, and all figures were created using these descriptive statistics. 
TABLE 2. Mean migration of nonpermanent greenline plots $(n=80)$ across the study season (weeks 1-20) for streams A-D. Measurements were taken from the center of the permanent greenline plot that was placed in June 2009 to the center of the nonpermanent plot placed in 2010. The values in parentheses (columns 3 and 5) are the number of plots (out of 80) that migrated.

\begin{tabular}{|c|c|c|c|c|c|c|}
\hline Stream & Week & $\begin{array}{c}\text { Mean migration } \\
\text { towards stream }(\mathrm{cm})\end{array}$ & $\mathrm{SE}$ & $\begin{array}{l}\text { Mean migration away } \\
\text { from stream }(\mathrm{cm})\end{array}$ & $\mathrm{SE}$ & $\begin{array}{c}\text { Plots that did } \\
\text { not migrate } \\
\text { (out of } 80)\end{array}$ \\
\hline A & $\begin{array}{r}1 \\
3 \\
5 \\
7 \\
9 \\
11 \\
14 \\
17\end{array}$ & $\begin{array}{r}9.6(22) \\
15.9(25) \\
18.7(37) \\
18.9(41) \\
23.0(50) \\
23.5(53) \\
25.5(54) \\
22.1(51)\end{array}$ & $\begin{array}{l}2.2 \\
3.3 \\
3.1 \\
3.2 \\
3.1 \\
2.9 \\
3.2 \\
2.841\end{array}$ & $\begin{array}{l}1.2(3) \\
0.2(1) \\
0.0(0) \\
1.1(2) \\
1.7(4) \\
0.6(2) \\
0.6(2) \\
1.3(3)\end{array}$ & $\begin{array}{l}0.7 \\
0.0 \\
0.0 \\
0.8 \\
0.9 \\
0.4 \\
0.4 \\
0.8\end{array}$ & $\begin{array}{l}55 \\
54 \\
43 \\
37 \\
26 \\
25 \\
24 \\
26\end{array}$ \\
\hline B & $\begin{array}{r}1 \\
3 \\
5 \\
7 \\
9 \\
11 \\
14 \\
17\end{array}$ & $\begin{array}{c}8.0(12) \\
11.8(18) \\
16.8(28) \\
15.5(33) \\
16.4(49) \\
19.2(52) \\
16.2(51) \\
17.0(52)\end{array}$ & $\begin{array}{l}2.6 \\
3.0 \\
3.3 \\
2.9 \\
2.6 \\
2.6 \\
2.6 \\
2.7\end{array}$ & $\begin{array}{l}1.1(1) \\
0.0(0) \\
0.0(0) \\
3.0(1) \\
0.0(0) \\
0.0(0) \\
0.2(1) \\
0.0(0)\end{array}$ & $\begin{array}{l}1.1 \\
0.0 \\
0.0 \\
3.0 \\
0.0 \\
0.0 \\
0.2 \\
0.0\end{array}$ & $\begin{array}{l}67 \\
62 \\
52 \\
46 \\
31 \\
28 \\
28 \\
28\end{array}$ \\
\hline C & $\begin{array}{r}1 \\
3 \\
5 \\
7 \\
9 \\
11 \\
14 \\
17\end{array}$ & $\begin{array}{r}2.9(10) \\
8.5(21) \\
15.9(40) \\
19.2(48) \\
20.0(50) \\
19.4(51) \\
20.4(55) \\
18.3(52)\end{array}$ & $\begin{array}{l}0.9 \\
1.9 \\
2.4 \\
2.6 \\
2.8 \\
2.5 \\
2.6 \\
2.5\end{array}$ & $\begin{array}{l}3.2(7) \\
0.4(2) \\
0.5(1) \\
1.500(4) \\
1.7(6) \\
2.5(7) \\
1.6(6) \\
1.8(5)\end{array}$ & $\begin{array}{l}1.3 \\
0.3 \\
0.5 \\
0.9 \\
0.7 \\
1.1 \\
0.7 \\
0.8\end{array}$ & $\begin{array}{l}63 \\
57 \\
39 \\
28 \\
24 \\
22 \\
19 \\
23\end{array}$ \\
\hline D & $\begin{array}{r}1 \\
3 \\
5 \\
7 \\
9 \\
11 \\
14 \\
17 \\
20\end{array}$ & $\begin{array}{r}0.3(1) \\
4.5(5) \\
8.4(11) \\
10.6(15) \\
15.9(32) \\
17.0(31) \\
16.5(34) \\
9.3(20) \\
10.1(20)\end{array}$ & $\begin{array}{l}0.3 \\
2.3 \\
3.3 \\
3.6 \\
3.6 \\
4.0 \\
3.7 \\
3.2 \\
2.8\end{array}$ & $\begin{array}{l}3.5(5) \\
5.0(5) \\
2.4(2) \\
2.6(2) \\
3.8(4) \\
3.9(4) \\
3.8(4) \\
3.6(4) \\
4.7(6)\end{array}$ & $\begin{array}{l}1.7 \\
2.3 \\
1.7 \\
1.9 \\
2.0 \\
2.0 \\
2.0 \\
1.8 \\
2.0\end{array}$ & $\begin{array}{l}74 \\
70 \\
67 \\
63 \\
44 \\
45 \\
42 \\
56 \\
54\end{array}$ \\
\hline
\end{tabular}

\section{RESUlts}

Over the growing season, we placed nonpermanent plots closer to the stream to track perennial vegetation emergence in the moist soil (Table 2). Even though there was some movement of nonpermanent greenline plots during the season, there were few differences between the results of the vegetation metrics of the 2 plot types. Plot type (permanent or nonpermanent) did not have a strong effect (even if it was statistically significant) on any of the response metrics in this study, and the 2 plot types mirrored each other for all of the response metrics (Fig. 3, Appendixes 1-3; Table 3). There were only a few occurrences where plot type was significant as a main effect, and there was no general pattern as to which metrics were significant (Table 3). Week was generally a significant effect, signifying that seasonal variation was strong in these metrics (Table 3). There was no evidence of an interaction of plot type and week (Table 3).

\section{Discussion}

We found that the vegetation metrics in our study did not differ between permanent and nonpermanent plots. In order to make sound scientific decisions about land management, monitoring efforts should be repeatable and yield reliable results (Coles-Ritchie et al. 2004), but they must also be logistically feasible. Given that we found no difference, we suggest that nonpermanent plots are preferable in small western streams because they are easier 


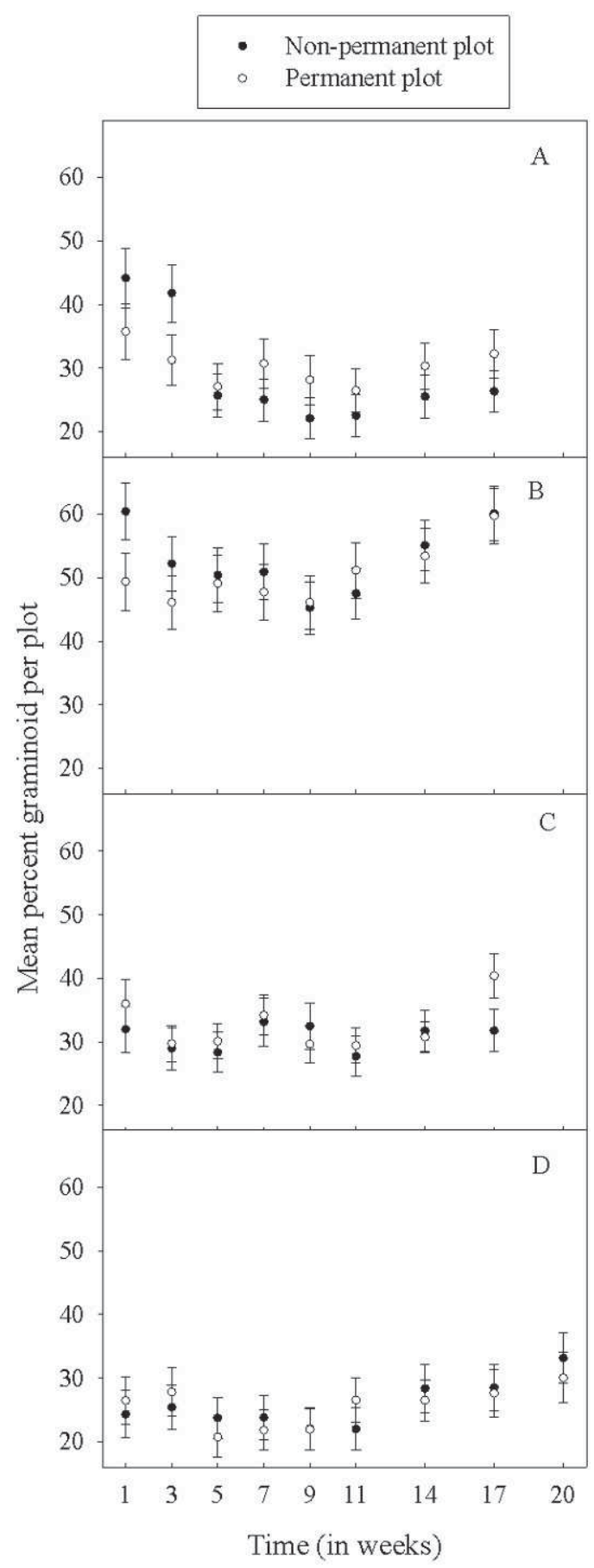

Fig. 3. Mean percent graminoid $( \pm 1 \mathrm{SE})$ per plot across the study season (weeks 1-20) for 2 different plot types (permanent and nonpermanent) at streams A-D (see Fig. 1). Standard errors are not related to significance tests in model results. See appendix figures for additional metric results. for researchers to place and are functionally advantageous for monitoring needs. Nonpermanent greenline plots are advantageous over permanent plots in small western streams because they are defined by their spatial relationship to the stream, rendering a permanent marker unnecessary. In addition, in floodplains, monuments used to mark permanent plots are susceptible to destruction by flood events. Because streams naturally migrate over long temporal scales (Naiman and Decamps 1997), nonpermanent greenline plots are able to migrate with the stream and capture the important hydric species of interest. There are instances where there could be a major change in greenline location, such as when beaver move into an area and re-engineer the stream channel (Naiman et al. 1988) or when there is a major flood event in even a short time period. In these exceptional cases, major changes in the ecosystem are of interest to land managers, and the new location is more important to study than the previous location, which may be under water or located distantly from the stream.

By using the PIBO (Leary and Ebertowski 2010) definition of greenline with the upper and lower limit constraint, we limited the greenline plot location within the stream bank, where riparian vegetation has important ecosystem functions such as stabilizing stream banks and reducing erosion (Belsky et al. 1999, Winward 2000). As a result, we saw little migration of the greenline plot during the study season within a site, and site location had far greater differences in response metrics. We observed minimal migrations of plots within a site and determined that site location was a prominent cause for differences in metrics. Using a constrained greenline location has advantages over similar greenline protocols, like those of the MIM or Winward approaches. These protocols base the location of greenline on a "continuous line of vegetation" (Winward 2000) or the first plot with $>25 \%$ perennial cover up to $6 \mathrm{~m}$ from the stream edge (Burton et al. 2011). These descriptors are vague and may result in a plot that is not within the streambank.

Although we may have found different results in larger systems (with greater flooding and stream dynamics), the scope of this research was focused on small streams ( $<6 \mathrm{~m}$ in width), where the majority of riparian monitoring 
TABLE 3. Statistical tests of fixed effects and interactions for a one-way ANOVA (with repeated measures in time) to test the effects of plot type and week on the response metrics: species richness (square-root transformed; Rsq), live vegetation cover (LVC), percent forb (square-root transformed; Fsq), litter and moss (L), bare ground (BG), wetland indicator rating (WIR), and percent graminoid (square-root transformed; Gsq). Num DF = numerator degrees of freedom, Den DF = denominator degrees of freedom.

\begin{tabular}{|c|c|c|c|c|c|c|c|c|c|c|}
\hline \multirow[b]{2}{*}{ Stream } & \multirow{2}{*}{$\begin{array}{l}\text { Response } \\
\text { metric }\end{array}$} & \multicolumn{3}{|c|}{ Plot type } & \multicolumn{3}{|c|}{ Week } & \multicolumn{3}{|c|}{ Plot type* Week } \\
\hline & & Num DF & Den DF & $F$ & Num DF & Den DF & $F$ & Num DF & Den DF & $F$ \\
\hline A & Rsq & 1 & 6.1 & 0.2 & 7 & 38.7 & $6.1^{* * *}$ & 7 & 38.8 & 0.9 \\
\hline $\mathrm{B}$ & & 1 & 9.8 & 0.9 & 7 & 40.3 & $10.0^{* * * *}$ & 7 & 40.3 & 0.3 \\
\hline $\mathrm{C}$ & & 1 & 7.6 & 5.3 & 7 & 36.4 & $16.4^{* * *}$ & 7 & 36.4 & 0.9 \\
\hline $\mathrm{D}$ & & 1 & 7.9 & 0.1 & 8 & 39.5 & $5.0^{* * *}$ & 8 & 39.5 & 1.1 \\
\hline A & WIR & 1 & 3.8 & 0.1 & 7 & 35.9 & $7.5^{* * *}$ & 7 & 35.9 & 0.2 \\
\hline B & & 1 & 5.6 & 2.8 & 7 & 31.3 & 1.5 & 7 & 31.3 & 0.8 \\
\hline $\mathrm{C}$ & & 1 & 8.9 & $12.0^{* *}$ & 7 & 39.4 & $3.1^{*}$ & 7 & 39.4 & 0.7 \\
\hline $\mathrm{D}$ & & 1 & 9.6 & 0.3 & 8 & 40.6 & $3.1^{* *}$ & 8 & 40.6 & 0.4 \\
\hline A & $\mathrm{LVC}$ & 1 & 4.0 & 1.2 & 7 & 37.2 & $16.9^{* * *}$ & 7 & 37.2 & 0.5 \\
\hline B & & 1 & 4.3 & 0.3 & 7 & 37.2 & $8.4^{* * *}$ & 7 & 37.2 & 0.2 \\
\hline $\mathrm{C}$ & & 1 & 10.1 & 1.8 & 7 & 41.2 & $16.5^{* * *}$ & 7 & 41.2 & 0.3 \\
\hline $\mathrm{D}$ & & 1 & 13.0 & $10.1^{* * *}$ & 8 & 40.8 & $27.6^{* * *}$ & 8 & 40.8 & 1.6 \\
\hline $\mathrm{A}$ & Fsq & 1 & 3.9 & 1.9 & 7 & 35.3 & $5.9^{* * *}$ & 7 & 35.3 & 1.2 \\
\hline B & & 1 & 3.1 & 0.1 & 7 & 39.0 & $4.1^{* *}$ & 7 & 39.0 & 0.8 \\
\hline $\mathrm{C}$ & & 1 & 8.5 & 0.3 & 7 & 35.6 & $4.3^{* *}$ & 7 & 35.6 & 1.2 \\
\hline $\mathrm{D}$ & & 1 & 3.4 & 0.8 & 8 & 43.1 & 2.1 & 8 & 43.1 & 0.7 \\
\hline A & Gsq & 1 & 4.1 & 0.0 & 7 & 39.6 & $2.6^{*}$ & 7 & 39.6 & 0.9 \\
\hline B & & 1 & 6.7 & 2.9 & 7 & 35.5 & $3.1^{*}$ & 7 & 35.5 & 1.0 \\
\hline $\mathrm{C}$ & & 1 & 6.6 & 4.1 & 7 & 35.5 & 1.7 & 7 & 35.5 & 0.6 \\
\hline $\mathrm{D}$ & & 1 & 4.5 & 0.0 & 8 & 40.4 & $3.1^{* *}$ & 8 & 40.5 & 0.9 \\
\hline A & $\mathrm{L}$ & 1 & 6.6 & $8.6^{*}$ & 7 & 36.3 & $17.8^{* * *}$ & 7 & 36.3 & 1.1 \\
\hline B & & 1 & 6.4 & 3.8 & 7 & 35.9 & $16.5^{* * *}$ & 7 & 35.9 & 0.2 \\
\hline $\mathrm{C}$ & & 1 & 9.9 & 0.2 & 7 & 39.5 & $12.4^{* * *}$ & 7 & 39.5 & 0.4 \\
\hline $\mathrm{D}$ & & 1 & 4.8 & 1.8 & 8 & 40.5 & $12.7^{* * *}$ & 8 & 40.5 & 0.9 \\
\hline A & BG & 1 & 6.3 & 0.0 & 7 & 38.5 & $2.4^{*}$ & 7 & 38.5 & 0.5 \\
\hline B & & 1 & 6.6 & 0.9 & 7 & 37.2 & $3.0^{*}$ & 7 & 37.2 & 0.5 \\
\hline $\mathrm{C}$ & & 1 & 9.8 & 4.3 & 7 & 40.4 & $9.4^{* * * *}$ & 7 & 40.4 & 1.8 \\
\hline $\mathrm{D}$ & & 1 & 4.3 & 0.3 & 8 & 40.7 & $2.4^{*}$ & 8 & 40.7 & 0.1 \\
\hline
\end{tabular}

${ }^{*}$ Effect significant at $P<0.050$

** Effect significant at $P<0.010$

**** Effect significant at $P<0.001$

occurs in the western United States. Approximately $90 \%$ of perennial stream and river miles in the United States are small, wadeable streams, and in the Interior Columbia Basin, the mean bankfull width of wadeable streams is $4.3 \mathrm{~m}$ (USEPA 2007). Because small streams are common and sensitive to changes in the environment (Savage and Rabe 1979), managers need sound practices for riparian monitoring, and standardizing these practices is useful.

In conclusion, we do not see a need for permanent greenline plots because nonpermanent plots yield similar results for the commonly used response metrics of riparian vegetation monitoring. Though permanent plots may be appropriate for terrestrial systems, nonpermanent plots are well suited to riparian monitoring in small western streams. Permanent plots are labor-intensive, may be destroyed by a naturally changing stream, and are difficult to relocate (Beever et al. 2005, Gerber et al. 2008). Nonpermanent plots are much quicker to place and monitor, and are less costly; thus, we suggest that they are a superior choice for riparian monitoring in small western streams.

\section{ACKNOWLEDGMENTS}

We thank the USDA Forest Service, Rocky Mountain Research Station, for funding this research. In addition, many thanks to F.E. Busby and Susan Durham for guidance and manuscript revisions. Thanks also to Cheyenne Guillois, Mark Vilardi, and Stacey Frisk for fieldwork assistance and Diane Menuz for database assistance. This research was supported by the Utah Agricultural Experiment Station, Utah State University, and approved as journal paper number 8592 . 


\section{Literature Cited}

Acker, S.A., S.V. Gregory, G. Lienkaemper, W.A. MCKee, FJ. Swanson, and S.D. Miller. 2003. Composition, complexity, and tree mortality in riparian forests in the central Western Cascades of Oregon. Forest Ecology and Management 173:293-308.

Bakker, J.P., H. OlfF, J.H. Willems, and M. Zobel. 1996. Why do we need permanent plots in the study of long-term vegetation dynamics? Journal of Vegetation Science 7:147-155.

Beever, E.A., D.A. Pyke, J.C. Chambers, F. Landau, and S.D. SMITH. 2005. Monitoring temporal change in riparian vegetation of Great Basin National Park. Western North American Naturalist 65:382-402.

Belsky, A.J., A. Matzke, and S. Uselman. 1999. Survey of livestock influences on stream and riparian ecosystems in the western United States. Journal of Soil and Water Conservation 54:419-433.

BunYavejChewin, S. 1999. Structure and dynamics in seasonal dry evergreen forest in northeastern Thailand. Journal of Vegetation Science 10:787-792.

Burton, T.A., S.J. Smith, And E.R. Cowley. 2011. Multiple indicator monitoring (MIM) of stream channels and streamside vegetation. Technical reference 1737-23, USDI Bureau of Land Management; [cited 14 June 2011]. Available from: http://www.blm.gov/nstc/library/ pdf/MIM.pdf

Coles-Ritchie, M.C., R.C. Henderson, E.K. Archer, C. Kennedy, and J.L. Kershner. 2004. Repeatability of riparian vegetation sampling methods: how useful are these techniques for broad-scale, longterm monitoring? General Technical Report RMRSGTR-138, U.S. Department of Agriculture, National Forest Service; [cited 14 June 2011]. Available from: http://www.fs.fed.us/rm/pubs/rmrs_gtr138.pdf

Gerber, E., C. Krebs, C. Murrell, M. Moretti, R. RoCKLin, AND U. SCHAFFner. 2008. Exotic invasive knotweeds (Fallopia spp.) negatively affect native plant and invertebrate assemblages in European riparian habitats. Biological Conservation 141:646-654.

Harrelson, C.C., C.L. Rawlins, AND J.P. Potyondy. 1994. Stream channel reference sites: an illustrated guide to field technique. General Technical Report RM245, USDA Forest Service, Fort Collins, CO; [cited 14 April 2012]. Available from:http://www.stream.fs fed.us/publications/PDFs/RM245E.PDF

LAINE, C.M. 2011. An assessment of vegetation metrics and plot types to measure seasonal variation and grazing effects on riparian plant communities. Master's thesis, Utah State University, Logan, UT.

LEARY, R.J., AND P.E. EBERTOWSKI. 2010. Effectiveness monitoring for streams and riparian areas: sampling protocol for vegetation parameters. Unpublished paper, USDA Forest Service; [cited 14 June 2011]. Available from: http://www.fs.fed.us/biology/resources /pubs/feu/pibo/pibo_veg_protocol_2010.pdf

LIANG, S.Y., AND S.W. SEAGLE. 2002. Browsing and microhabitat effects on riparian forest woody seedling demography. Ecology 83:212-227.
Naiman, R.J., And H. DeCamps. 1997. The ecology of interfaces: riparian zones. Annual Review of Ecology and Systematics 28:621-658.

Naiman, R.J., C.A. Johnston, and J.C. Kelley. 1988. Alteration of North American streams by beaver. BioScience 38:753-762.

Pickett, S., S. Collins, and J. Armesto. 1987. A hierarchical consideration of causes and mechanisms of succession. Plant Ecology 69:109-114.

REED, P.B. 1988. National list of plant species that occur in wetlands: 1988 national summary. Biological report $88(24)$, USDI Fish and Wildlife Service; [cited 14 June 2011]. Available from: http://www.fws.gov /pacific/ecoservices/habcon/pdf/National\%20List $\% 2$ 0of\%20Plant\%20Species\%201988.pdf

SAKIO, H. 1997. Effects of natural disturbance on the regeneration of riparian forests in a Chichibu Mountains, central Japan. Plant Ecology 132:181-195.

SATTERThWAITE, F.E. 1946. An approximate distribution of estimates of variance components. Biometrics Bulletin 2:110-114.

SAS Institute, INC. 2008. SAS for Windows, version 9.2 [software].

SaVage, N.L., AND F.W. Rabe. 1979. Biological Conservation 15:301-315.

Scherrer, P., AND C. Pickering. 2005. Recovery of alpine vegetation from grazing and drought: data from long-term photoquadrats in Kosciuszko National Park, Australia. Arctic, Antarctic, and Alpine Research 37:574-584.

TAвACCHI, E. 1995. Structural variability and invasions of pioneer plant communities in riparian habitats of the middle Adour River (SW France). Canadian Journal of Botany 73:33-44.

Van Pelt, R., T.C. O’Keefe, J.J. Latterell, and R.J. NAIMAN. 2006. Riparian forest stand development along the Queets River in Olympic National Park, Washington. Ecological Monographs 76:277-298.

WINWARD, A.H. 2000. Monitoring the vegetation resources in riparian areas. General Technical Report RMRSGTR-47, USDA Forest Service; [cited 14 June 2011]. Available from: http://www.fs.fed.us/rm/pubs/rmrs_g tr047.pdf

[USDA-NRCS] United States Department of Agriculture, Natural Resources Conservation SerVICE. 2011. The Plants Database [online]. National Plant Data Team; [cited 14 June 2011]. Available from: http://plants.usda.gov

[USEPa] United States Environmental Protection AgEnCy. 2007. Ecological condition of wadeable streams of the Interior Columbia Basin. EPA 910-R07-005; [cited 25 April 2012]. Available from: http:// www.epa.gov/emap/west/html/docs/ICBFinal07.pdf

World Climate. 2011. Robert Hoare. 5 May 2011. Available from: http://www.worldclimate.com

Received 10 October 2012 Accepted 29 May 2013 


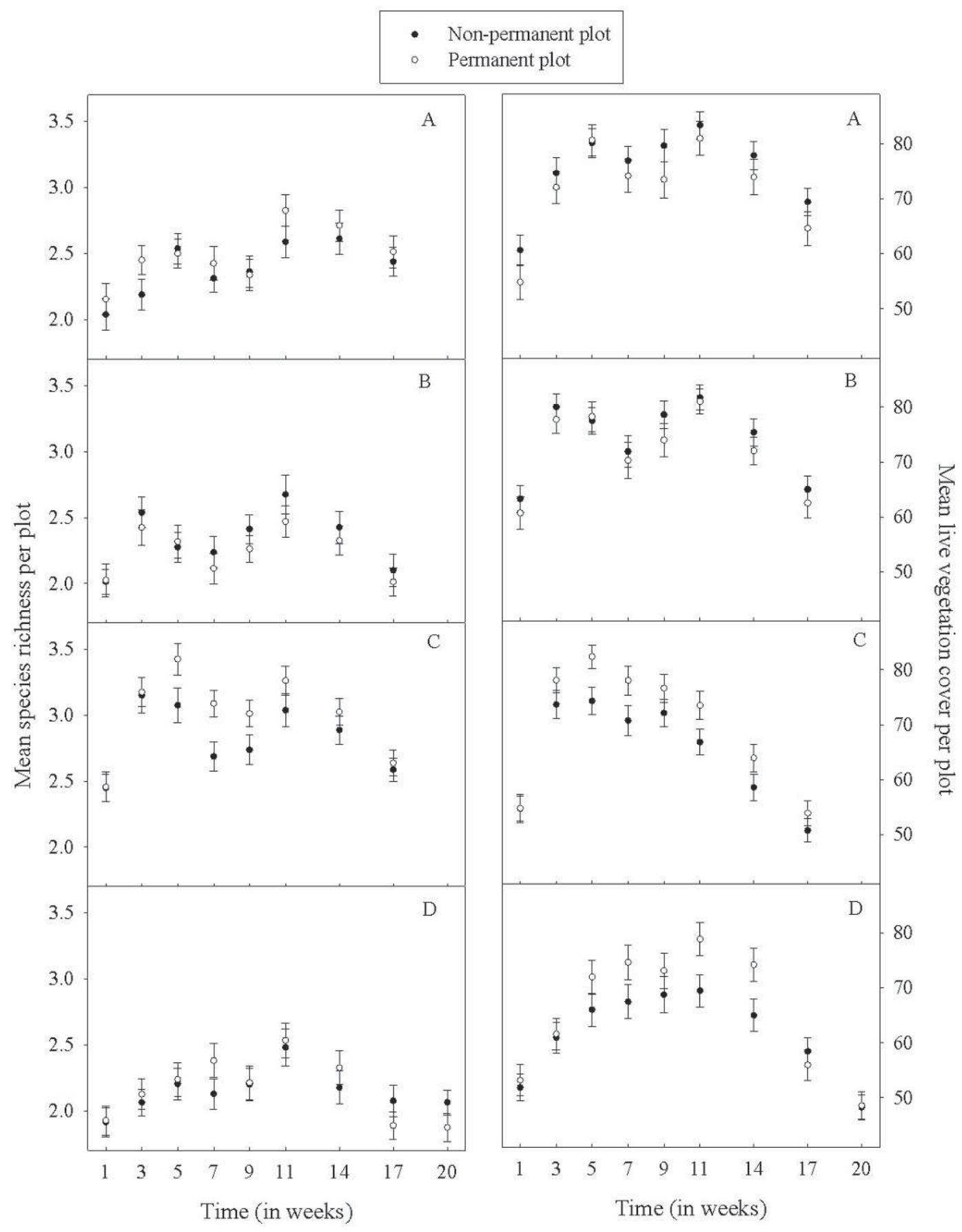

APPENDIX 1. Mean species richness $( \pm 1 \mathrm{SE})$ and mean percent live vegetation cover $( \pm 1 \mathrm{SE})$ per plot across the study season (weeks 1-20) for 2 different plot types (permanent and nonpermanent) at streams A-D (see Fig. 1). Standard errors are not related to significance tests in model results. 


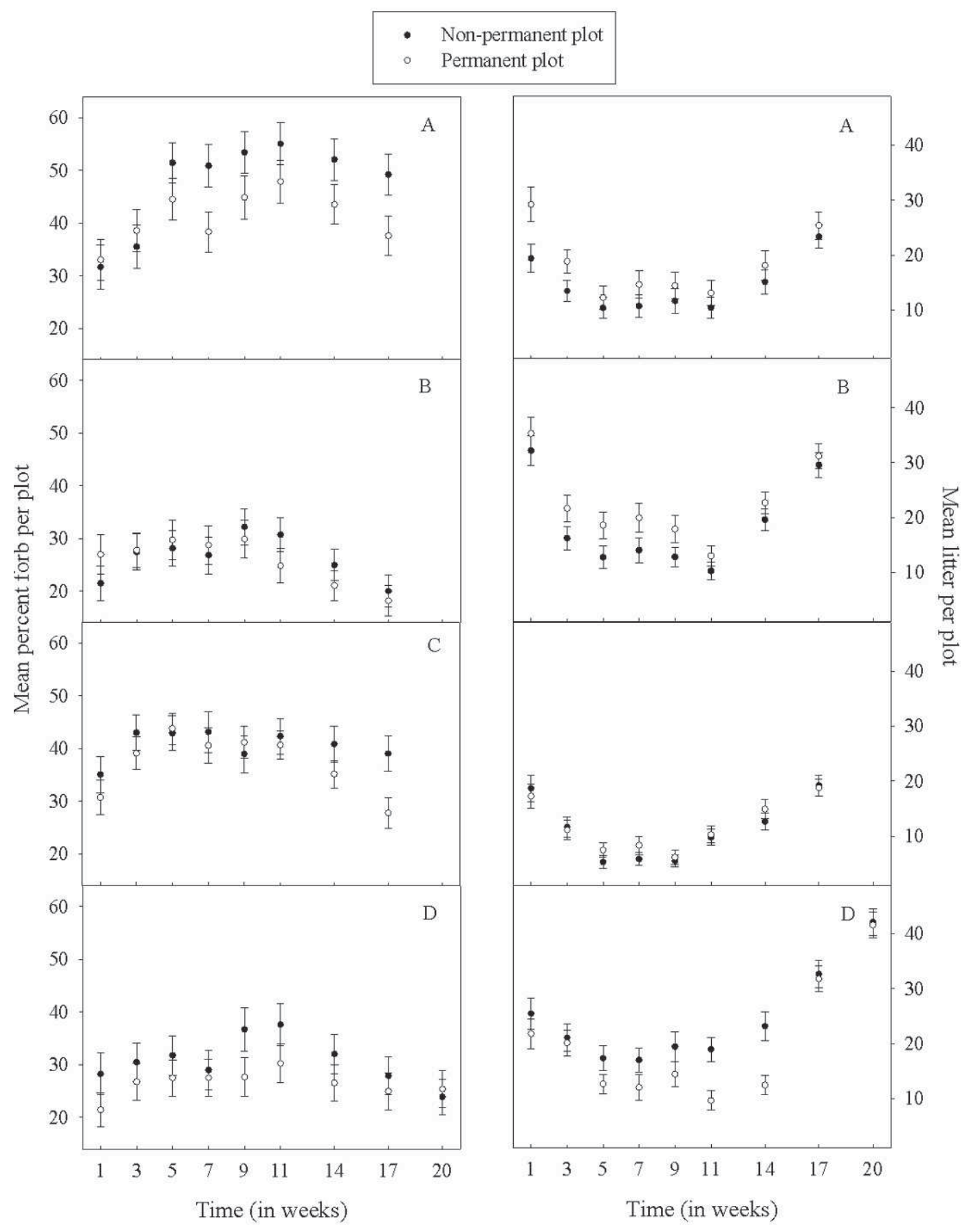

APPENDIX 2. Mean percent forb $( \pm 1 \mathrm{SE})$ and mean percent litter $( \pm 1 \mathrm{SE})$ per plot across the study season (weeks 1-20) for 2 different plot types (permanent and nonpermanent) at streams A-D (see Fig. 1). Standard errors are not related to significance tests in model results. 


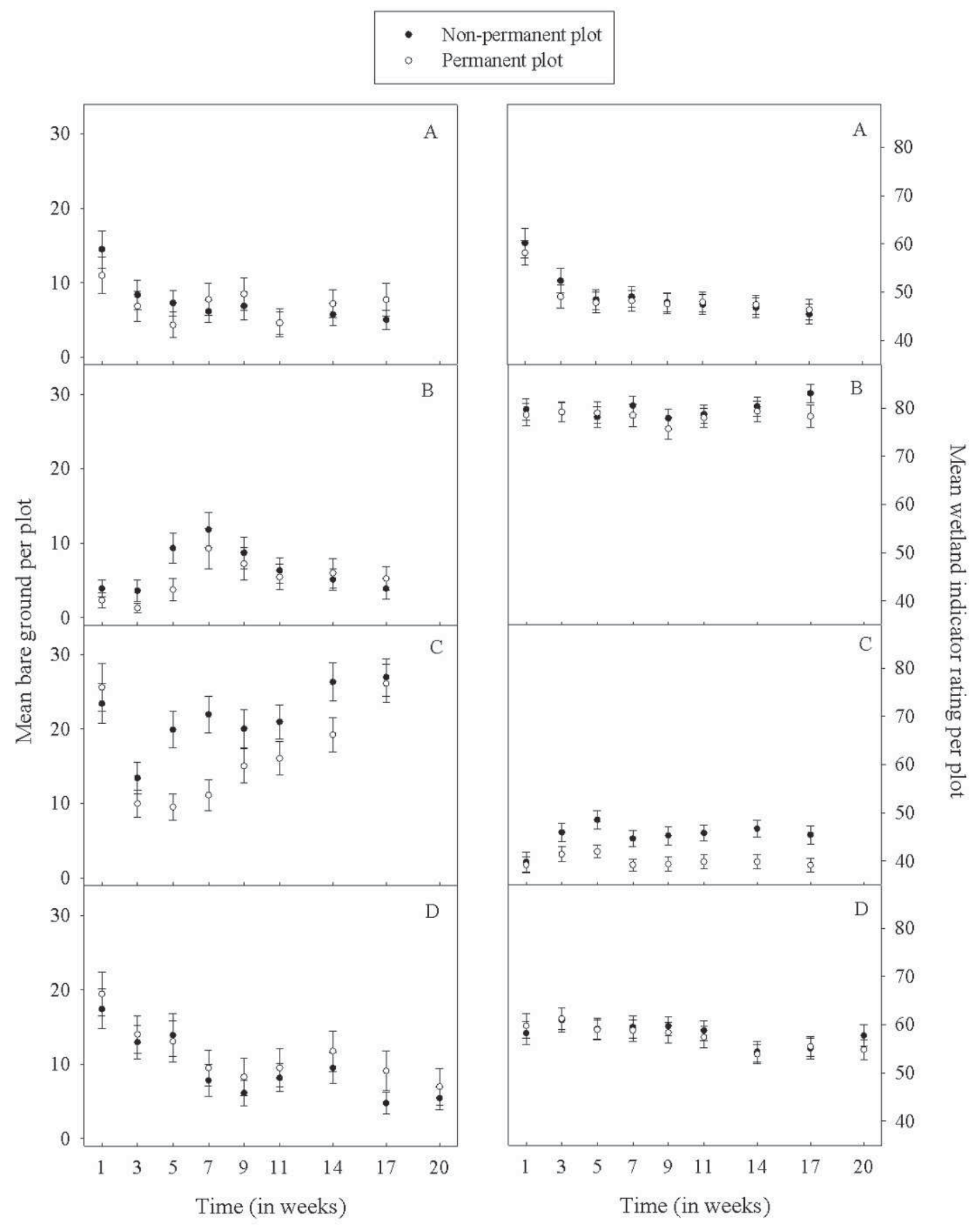

APPENDIX 3. Mean percent bare ground $( \pm 1 \mathrm{SE})$ and mean wetland indicator rating ( $\pm 1 \mathrm{SE})$ per plot across the study season (weeks 1-20) for 2 different plot types (permanent and nonpermanent) at streams A-D (see Fig. 1). Standard errors are not related to significance tests in model results. 